\title{
Prognostic predictor at Pediatrics Intensive Care Unit (PICU) with Pediatric Risk of Mortality III (PRISM III) scores
}

\author{
Vita Susianawati ${ }^{1 *}$, Purnomo Suryantoro ${ }^{2}$, Roni Naning ${ }^{2}$ \\ 'PKU Hospital Delanggu, Klaten, 2Departement of Pediatrics, Faculty of Medicine, \\ Universitas Gadjah Mada/ Dr. Sardjito Hospital, Yogyakarta
}

\begin{abstract}
Various mortality prognostic scoring system are available for predicting mortality risk in Pediatric Intensive Care Unit (PICU). The Pediatric Risk of Mortality III (PRISM III) scoring system is one of the main indicators used in the PICU. This study was conducted to evaluate the PRISM III as prognostic predictor in PICU. This was a cohort study involving 64 patients who admitted to PICU in Dr. Sardjito General Hospital, Yogyakarta and met inclusion and exclusion criteria. The clinical state of patients were assessed and the PRISM III scores corresponding to the firs 24 hours of hospitalization were calculated. Outcome analysis was defined either as death or discharged from the hospital were recorded. Multivariate analysis was performed to find out independent predictive factor that influence the outcome of death. The discriminative power of the model was calculated based on the receiver operator curve (ROC). The result showed that mental status (relative risk/RR: 13.21; $95 \% \mathrm{Cl}$ : 1.18-14.80), White Blood Count/WBC (RR: 19.51; 95\% Cl: 18.12-25.15) and Blood Urea Nitrogen/BUN (RR:22.87; 95\% Cl:1.85-28.20) were found to be the main predictive factors of death in PICU. The cut off value of 51 of PRISM III score yielded the best sensitivity $(83 \%)$ and specificity $(69 \%)$. In conclusion, PRISM III score can be used as a prognostic predictor to determine the death risk of patients hospitalized at PICU.
\end{abstract}

\section{ABSTRAK}

Berbagai sistem penilain prognosis mortalitas tersedia untuk memprediksi risiko kematin di Uni Perawatan Insentif Anak (UPIA). Sistem penilaian Pediatric Risk of Mortality III (PRISM III) merupakan salah satu indikator utama yang digunakan di UPIA. Penelitian ini dilakukan untuk mengkaji PRISM III sebagai pridiktor prognosis di UPIA. Penelitian ini merupakan penelitian kohort yang melibatkan 64 pasien anak yang dirawat di UPIA RSUP Dr. Sardjito, Yogyakarta yang memenuhi kriteria inklusi dan eksklusi. Kondisi klinik pasien diperiksa dan nilai PRISM III pada 24 jam pertama sejak dirawat di rumah sakit dihitung. Analisis multivariat dilakukan untuk mencari faktor prediktif independen yang mempengaruhi kematian. Kekuatan pembeda model dihitung berdasarkan receiver operator curve (ROC). Hasil penelitian menunjukkan status mental (Relative Risk/RR: 13,21; 95\% Confidence Interval/Cl: 1,18-14,80), jumlah leukosit (RR: 19,51; $95 \% \mathrm{Cl}: 18,12-25,15)$ and nitrogen urea darah (RR:22,87; $95 \% \mathrm{Cl}: 1,85-28,20)$ terbukti merupakan faktor prediktif utama kematian di UPIA. Nilai titik potong 50 dari skor PRISM III memberikan senstitivitas (83\%) dan spesifisitas (69\%) terbaik. Dapat disimpulkan, skor PRISM III dapat digunakan sebagai prediktor prognostik untuk menentukan risiko kematian pasien yang dirawat di UPIA.

Keywords: prognostic - Pediatrics Intensive Care Unit - PRISM III - death risk - predictor

\footnotetext{
* corresponding author: vita_susiana@yahoo.com
} 


\section{INTRODUCTION}

Pediatrics intensive care unit (PICU) is an intensive care unit that provides treatment and care of critically ill children. Pediatrics ICU aim at promoting qualified care with the objective of achieving the best results and better progress for the critically ill children. The practice of PICU has developed dramatically throughout the past 3 decades. Knowledge of the pathology of life-threatening processes and the technological capacity to monitor and treat pediatric patients suffering from them has advanced rapidly during this period. Therefore, the aim of PICU to suppress the number of deaths (mortality) and the rate of disability (morbidity) can be achieved. ${ }^{1-3}$

Technology advances in PICU resulted to a more sophisticated care for children, therefore making the PICU prepared to treat cases of high complexity at high cost. However, the technology available has no always succeeded in improving the quality of patient care and to augment life expectancy. ${ }^{4}$ Thefore, measuring the ilness severity at admission and assessing its prognosis are needed..$^{5.6}$ This procedure can be conducted using the mortality prognostic scores that objectively quantify the ilness severity and predict the mortality risk according to the clinical state of patients. In addition, the mortality prognosis scores could aid in various areas of treatment and care, such as selection of treatments, ethical issues and economic strategies. $^{7}$

Various mortality prognostic scoring system are available for predicting mortality risk in PICU. The Pediatric Risk of Mortality (PRISM ) scoring system is one of the main indicators used in the PICU. The PRISM is a physiologybased predictor for PICU patients. Recently, a new scoring system, PRISM III, an updated second generation scoring system, has been validated for use in the United States and several other countries. PRISM III has resulted in several improvements over the original PRISM. In addition, PRISM III has an important role in clinical study protocols as it acts as a severity index for patient comparison. ${ }^{8,9}$

The purpose of this study was to evaluate the use of PRISM III scores as prognostic predictor of mortality at PICU of Dr. Sardjito General Hospital, Yogyakarta.

\section{MATERIAL AND METHODS}

\section{Subjects}

A prospective cohort conducted in patients who admitted at the PICU of Dr. Sardjito General Hospital, Yogyakarta, starting from December 2012 until an appropriate sample size obtained. A minimum of 52 patients were estimated to be necessary for the present study. The sample size was calculated using sample size estimation for prognostic test. The inclusion criteria were children treated in the PICU whose parents agreed to follow the study by signing an informed consent, while the exclusion criteria was patients that have incomplete data. The study was approved by the Medical and Health Research Ethics Committee, Faculty of Medicine, Universitas Gadjah Mada, Yogyakarta.

\section{Research procedure}

The clinical state of patients who admitted at PICU were assessed and the PRISM II scores corresponding to the firs 24 hours of hospitalization were determined. The PRISM III scores were calculated according to the equation described by Pollack et al. ${ }^{6}$ This involved age-related physiological parameters, including mental status, systolic blood pressure (SBP), heart rate (HR), blood urea nitrogen (BUN), creatinine, pupillary reflexes, temperature, white blood count (WBC), platelet count, acidosis ( $\mathrm{pH}$ and total $\mathrm{CO}_{2}$ ), $\mathrm{pCO}_{2}, \mathrm{pO}_{2}$, 
glucose, potassium and prothrombin time or partial thromboplastin time (PT/aPTT). Outcome analysis was defined either as death or discharged from the hospital were recorded.

\section{Statistical analysis}

Data were tabulated and analyzed using SPSS version 15. Bivariate analysis was performed on PRISM III to find out predictive factors that influence the outcome of death. Whereas multivariate analysis was performed to find out independent predictive factor that influence the outcome of death. $p$ value $<0.05$ was considered indicative of statistical significance. The discriminative power of the model i.e. its ability to distinguish patients who would survive from those who would die was calculated based on the receiver operator curve (ROC).

\section{RESULTS}

Sixty-four children who met the inclusion and exclusion criteria were enrolled in this study with clinical outcome was 28 children alive (43.6\%) and 36 children died (56.4\%). The characteristics of subjects are presented in TABLE 1. Among 36 of the death cases, 7 $(19.4 \%)$ deaths were surgical cases and 29 $(80.6 \%)$ deaths were non-surgical cases. The main cause of death on non-surgical cases included intracranial infection $(40.8 \%)$, pneumonia $(23.8 \%)$, malignancy $(10.2 \%)$, intracranial bleeding (10.2\%) and dengue shock syndrome, diabetic ketoacidosis.

TABLE 1. Characteristics of subjects

\begin{tabular}{lcccc}
\hline \multirow{2}{*}{ Characteristics } & \multicolumn{2}{c}{ Alive } & \multicolumn{2}{c}{ Dead } \\
\cline { 2 - 5 } & $\mathrm{n}$ & $\%$ & $\mathrm{n}$ & $\%$ \\
\hline Age & & & & \\
- $1-12$ months & 6 & 9.3 & 10 & 15.6 \\
- $13-60$ months & 20 & 31.2 & 16 & 25.2 \\
- $>60$ months & 2 & 3.1 & 10 & 15.6 \\
Gender & & & & \\
- Male & 17 & 26.5 & 19 & 29.7 \\
- Female & 11 & 17.3 & 17 & 26.5 \\
\hline
\end{tabular}

Bivariate analysis performed on the PRISM III to find out predictive factors that influence of death showed that mental status, white blood count, HR and BUN were predictive factors of deatah in PICU (TABLE 2). 
TABLE 2. Bivariate analysis of predictive factors of death

\begin{tabular}{lcccc}
\hline \multirow{2}{*}{ Predictive factors } & $\mathrm{p}$ & Relative & \multicolumn{2}{c}{$95 \% \mathrm{CT}$} \\
\cline { 5 - 6 } & & Risk & Lower & Upper \\
\hline Mental status & $0.011^{*}$ & 3.93 & 1.36 & 11.33 \\
Systolic blood pressure & 0.235 & 0.42 & 0.35 & 2.65 \\
Heart rate & $0.008^{*}$ & 4.58 & 1.5 & 14.00 \\
$\mathrm{BUN}$ & $0.001^{*}$ & 10.51 & 3.29 & 33.55 \\
Creatinine & 0.001 & 2.67 & 0.96 & 7.39 \\
Pupillary reflexes & 0.481 & 1.44 & 0.84 & 3.87 \\
Temperature & 0.629 & 0.464 & 3.55 & 1.28 \\
WBC & $0.001^{*}$ & 73.88 & 8.70 & 78.10 \\
Platelet count & 0.073 & 5.27 & 0.85 & 32.62 \\
pH & 0.001 & 0.14 & 0.04 & 0.43 \\
$\mathrm{CO}_{2}$ & 0.225 & 1.43 & 0.65 & 7.54 \\
Acidosis & 0.002 & 0.11 & 0.03 & 0.37 \\
$\mathrm{pCO}_{2}$ & 0.001 & 0.10 & 0.03 & 0.37 \\
$\mathrm{pO}_{2}$ & 0.014 & 0.21 & 0.06 & 0.72 \\
$\mathrm{Glucose}$ & 0.001 & 0.13 & 0.04 & 0.42 \\
$\mathrm{Potassium}_{\mathrm{PT}_{\text {alaPT }}}$ & 0.620 & 1.36 & 0.38 & 4.75 \\
\hline
\end{tabular}

BUN: blood urea nitrogen; WBC: white blood count; *significantly different $(p<0.05)$.

Multivariate analysis performed to find out independent predictive factor that influence of death is presented in TABLE 3 . The predictive factors of death observed in this study were mental status with a relative risk (RR) of 13.21 (95\% CI 1.18 to 14.80$)$, WBC with RR of 19.51 (95\% CI 18.12 to 25.15$)$ and BUN with RR of 22.87 (95\% CI 1.85 to 28.20 ).

TABLE 3. Multivariate analysis

\begin{tabular}{|c|c|c|c|c|}
\hline \multirow{2}{*}{ Predictor factors } & \multirow{2}{*}{$\mathrm{p}$} & \multirow{2}{*}{$\begin{array}{c}\text { Relative } \\
\text { Risk }\end{array}$} & \multicolumn{2}{|c|}{$95 \% \mathrm{CI}$} \\
\hline & & & Lower & Upper \\
\hline Mental status & 0.036 & 13.21 & 1.18 & 14.80 \\
\hline White blood count & 0.001 & 19.51 & 18.12 & 25.15 \\
\hline BUN & 0.015 & 22.87 & 1.85 & 28.20 \\
\hline
\end{tabular}

To determine the discriminative power that distinguished patients who would survive from those who would die on PRISM scores, cut off point was calculated based on the receiver operator curve (ROC) as presented in FIGURE 1 . 


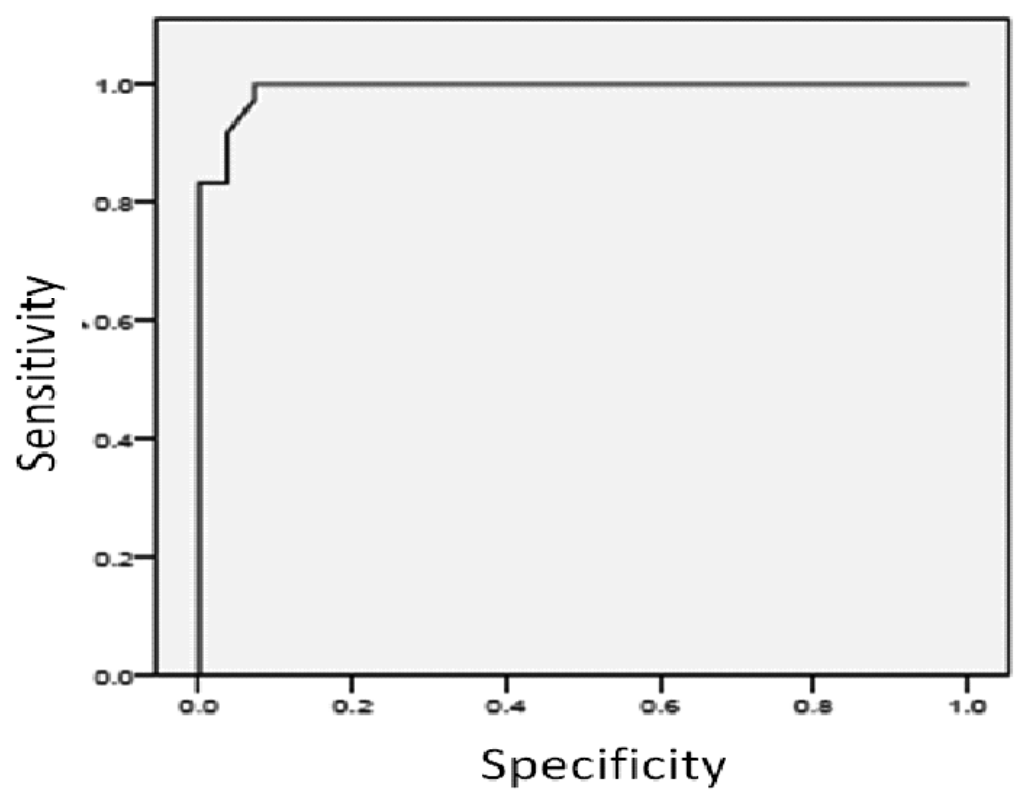

FIGURE 1. Receiver Operator Curve of sensitivity and specificity of PRISM III scores to determine the outcome (alive-dead)

TABLE 4 shows death prediction obtained from 64 patients based on the cut off point of the PRISM III scores. In this study, the cut off value of 51 gave the best sensitivity $(83 \%)$ and specificity (69\%), therefore it was taken as the cut off point. On cut off value of 26-41, high sensitivity but low specificity were observed, while on cut off value of 51-62, high specificity but low sensitivity were observed.

TABLE 4. Prediction of death compared in ROC of PRISM III scores

\begin{tabular}{lcc}
\hline $\begin{array}{c}\text { PRISM III } \\
\text { Score }\end{array}$ & $\begin{array}{c}\text { Sensitivity } \\
(\%)\end{array}$ & $\begin{array}{c}\text { Specificity } \\
(\%)\end{array}$ \\
\hline $\mathbf{2 6}$ & 100 & 0 \\
$\mathbf{3 0}$ & 100 & 54 \\
$\mathbf{3 7}$ & 100 & 54 \\
$\mathbf{4 1}$ & 100 & 64 \\
$\mathbf{4 9}$ & 89 & 65 \\
$\mathbf{5 1}$ & 83 & 69 \\
$\mathbf{5 4}$ & 69 & 100 \\
$\mathbf{5 7}$ & 36 & 100 \\
$\mathbf{6 0}$ & 22 & 100 \\
$\mathbf{6 2}$ & 11 & 100 \\
\hline
\end{tabular}




\section{DISCUSSION}

In this study, the death cases in non surgical cases $(80.6 \%)$ was higher than in surgical cases (19.4\%). This result was similar with primary data obtained from the same PICU in 2011 that showed the death cases in non surgical cases $(91.7 \%)$ was higher than in surgical cases $(8.3 \%)$. However, the main cause of death in this study was different with at the same PICU in 2011 which pneumonia (29.9\%) was the main cause of death, followed by intracranial infection $(14.0 \%)$ and cardiac abnormalities $(8.9 \%)$.

In this study, mental status, WBC and BUN were found to be the main predictive factors of death at PICU. This result was different with some other studies. De Leon et al. ${ }^{10}$ reported that main factors affecting death were pupillary reflexes (OR: 9.9; 95\% CI: 3.5-28.4), acidosis (OR: 31.1; 95\% CI: 2.0-4.9), BUN (OR:1.03; 95\% CI: $1.01-1.04$ ) and WBC (OR: $1.02 ; 95 \%$ CI: 1.01-1.03). Another study conducted at PICU in Dr. Sardjito General Hospital reported that the main factors affecting death were WBC and creatinine. ${ }^{11}$ The difference in the characteristics of patients may determine the main predictive factors of death in PICU.

In this study showed that the cut off value of 51 yielded the best sensitivity (83\%) and specificity (69\%). Therefore, it is taken as the cut off point of PRISM score. The cut off point value obtained in this study was different compare to that obtained in previous studies. De Leon et al. ${ }^{10}$ reported the cutoff point of 13 with sensitivity of $71 \%$ and specificity of $64 \%$, while Tan et al. ${ }^{8}$ reported the cutoff point of 18. The severity of illness may cause the difference in the cut off point of PRISM score obatained in each study. The patients admitted at PICU unit in Dr. Sardjito General Hospital during this study had quite severe illness conditions. Therefore the cut off point on the
ROC curve was quite high. The high mortality rate $(38.0 \%)$ at the PICU suported this data.

Performance of PRISM III score to predict mortality risk of children in PICU are influenced several factors. A study conducted in South Africa find poor discriminatory performance of the PRISM III score in intensive care unit. Over prediction at high PRISM score is observed due to the different demographic characteristics and different pattern of illness. ${ }^{5,12}$ In addition, higher mortality rate is observed in patietns with endotracheal intubation, central venous catheter and sepsis compare to the PRISM III score prediction. ${ }^{13-15}$ Patients aged less than 12 months who admitted to PICU have high mortality risk. ${ }^{16}$ However, factors that influenced performance of PRISM III score are not invetigated in this study.

\section{CONCLUSION}

In conclusion, PRISM III score can be used as a prognostic predictor to determine the outcome of death of patients hospitalized at PICU. Mental status, WBC and BUN are found to be the main predictive factors of death at PICU in Dr. Sardjito General Hospital. The the cut off value of 51 yields the best sensitivity $(83 \%)$ and specificity (69\%).

\section{ACKNOWLEDGEMENTS}

We would like to thank all patients and their parents who willing to participate in this study.

\section{REFERENCES}

1. Martha VF, Garcia PC, Piva JP, Einloft PR, Bruno F, Rampon V. Comparison of two prognostic scores (PRISM and PIM ) at a pediatric intensive care unit. J Pediatr (Rio J). 2005; 81(3):259-64.

2. Rosenberg D, Moss MM, The American College of Critical Care Medicine of the Society of Critical Care Medicine. Guidelines and levels of care for pediatric intensive care units. Crit Care Med 2004; 32 (10):2117-27. 
3. Lunberg K. ICU plays major role in care of terminaly ill children study reports to society of critical care medicine [internet]. Science Blog. 2003 [cited 2010 Apr 10]. Available from: http:// scienceblog.com/community/older/archives/K/3/ pub3774.html

4. de Araujo Costa G, Delgado AF, Ferraro A, Okay TS. Application of the Pediatric Risk of Mortality Score (PRISM) score and determination of mortality risk factors in a tertiary pediatric intensive care unit. Clinics 2010; 65(11): 1087 92.

5. Brady AR, Harrison D, Black S, Jones S, Rowan $\mathrm{K}$, Pearson G, et al. Assesment and optimization of mortality prediction tool for admission to pediatric intensive care unit in the United Kingdom. Pediatrics 2006; 117(4):e733-42.

6. Pollack MM, Patel KM, Ruttimann UE. PRISM III: an updated pediatric risk of mortality score. Crit Care Med 1996; 24(5):743-52.

7. Gunning $\mathrm{K}$, Rowan $\mathrm{K}$. $\mathrm{ABC}$ of intensive care: outcome data and scoring systems. BMJ 1999;319:241-4.

8. Tan GH, Tan TH, Goh DY, Yap HK. Risk factors for predicting mortality in a pediatric intensive care unit. Ann Acad Med Singapore 1998; 27(6):813-8.

9. Bhadoria P, Bhagwat AG. Severity scoring systems in paediatric intensive care units. Indian J Anaest 2008;52:Suppl (5):663-75.
10. de Leon AL, Romero-Guiterez G, Velenzuela CA, Gonzales-Bravo FE. Simplified PRISM III score and outcome in the pediatric intensive care unit. Pediatr Int 2005; 47(1):80-3.

11. Yustinah and Nurnaningsih. Simplified PRISM III score and mortality in PICU. 14th Indonesian Congress of Pediatric; 2008 July 2-5; Surabaya: Ikatan Dokter Anak Indonesia.

12. Wells M, Riera-Fanego JF, Luyt DK, Dance M, Lipman J. Poor discriminatory performance of the Pediatric Risk of Mortality (PRISM) score in a South African intensive care unit. Crit Care Med 1996;24:1507-13.

13. Maulen-Radovan I, Gutierrez-Castrellon P, Zaldo Rodriguez R, Martinez Natero O. PRISM score evaluation to predict outcome in pediatric patients on admission at an emergency department. Arch Med Res 2006; 27(4):553-8.

14. El Nawawi A. Evaluation of the outcome of patients admitted to the pediatric insentive care unit in Alexandria using the Pediatric Risk of Mortality (PRISM) score. J. Trop Pediatr 2003; 49(2): 109-14.

15. Peters M, Dobson S, Novelli V, Balfour J, Macnab A. Sepsis and fever. In: Macnab AJ, Macrae DJ and Henning, RJ. editors. Care of the critically ill child. London: Churchill Livingstone 1999: 103-19.

16. Proulx F. Timing and predictors of death in pediatric patients with multiple organ system failure. Crit Care Med 1994; 22:1025-31. 